\title{
Managing Bull Fertility in Beef Cattle Herds ${ }^{1}$
}

Gary R. Hansen ${ }^{2}$

Reproductive success is essential for cow/calf producers to be profitable. Research has shown that a one percent change in reproductive performance will generate up to 3 times more return on investment for cow/calf operators when compared to a one percent change in production and/or product performance. Fertility in a beef herd is a combination of cow fertility, bull fertility, cows detected in estrus, and cows mated, all of which are multiplicative. If one factor is low, the overall fertility of the cow herd is low (table 1). Assuming nutritional status and disease prevention is adequate, cow fertility is important on an individual basis while bull fertility is important across the whole cow herd as bulls can affect reproductive success across several females. This problem is exacerbated in single-sire herds where an infertile bull leads to reproductive failure of the cow herd which results in economic disaster.

The purpose of this paper is to discuss how producers can evaluate and manage bull fertility within beef cattle herds. Bull fertility is a combination of several factors including but not limited to: semen morphology, semen motility, libido, body condition score, ability to copulate, scrotal circumference, freedom from reproductive diseases and presence of specific binding proteins found in seminal fluid. High bull fertility implies that a bull is capable of impregnating large numbers of cows in a short breeding season. In order to determine a bull's breeding ability, all of the factors previously mentioned must be assessed. The five major problems in bulls of low fertility are listed below.

\section{Herd Health}

Disease prevention in bulls should be essentially the same as in breeding females. New animals, especially bulls, should be screened by a qualified veterinarian for infectious agents prior to entering a new herd. Purchase bulls only from reputable seedstock producers with adequate herd health plans. It is recommended to purchase virgin bulls where possible. Vaccinate all animals for leptospirosis (5-way lepto) and campylobacteriosis (formerly know as vibriosis) upon arrival to your location and follow up with an annual booster to insure adequate protection. New animals should be quarantined (30 days) before being placed with breeding females. Bulls should be tested annually for brucellosis; however, bulls should not be vaccinated for brucellosis. In some instances bulls need to be vaccinated for bovine viral diarrhea (BVD), infectious bovine rhinotracheitis (IBR) and trichomoniasis. It is wise to consult with a local veterinarian concerning disease prevalence in a given

1. This document is AN153, one of a series of the Animal Science Department, Florida Cooperative Extension Service, Institute of Food and Agricultural Sciences, University of Florida. Original publication date February 2006. Visit the EDIS Web Site at http://edis.ifas.ufl.edu.

2. Hansen, G.R., Assistant Professor of Animal Science, University of Florida, NFREC Marianna.

The Institute of Food and Agricultural Sciences (IFAS) is an Equal Opportunity Institution authorized to provide research, educational information and other services only to individuals and institutions that function with non-discrimination with respect to race, creed, color, religion, age, disability, sex, sexual orientation, marital status, national origin, political opinions or affiliations. U.S. Department of Agriculture, Cooperative Extension Service, University of Florida, IFAS, Florida A. \& M. University Cooperative Extension Program, and Boards of County Commissioners Cooperating. Larry Arrington, Dean 
locale. Each producer should follow up with an appropriate herd health plan to prevent transmission of reproductive diseases between animals.

Control of internal and external parasites should also be considered as part of the overall herd health program. Parasites can dramatically reduce body condition scores (energy reserves) of breeding bulls which can lead to reduced vigor, thus impacting reproductive performance in the cow herd. Products are available for the control of external and internal parasites and the return in increased performance usually out weighs any cost incurred.

\section{Nutrition}

Body condition scoring (BCS, Scale 1 to 9; $1=$ thin and $9=$ obese) of bulls is important in assessing a bull's energy reserves. Bulls should be in BCS 5 or better prior to being turned out with the cows. This is critical as bulls can lose up to several hundred pounds of body weight during the breeding season. Dramatic weight loss leads to lower sperm quality and production. Bulls in poor body condition at the start of the breeding season will likely compromise herd fertility leading to lower than optimum reproductive rates. Mature bulls need approximately $8 \%$ crude protein $(\mathrm{CP})$ intake to maintain $\mathrm{BCS}$, while bulls in poor condition need at least $10 \% \mathrm{CP}$ intake for weight gain. A medium to high quality energy source (i.e.52- 58\% total digestible nutrients [TDN]) should be available at all times. Young bulls need approximately 10 to $12 \% \mathrm{CP}$ and access to a high quality energy source (i.e. $58 \%$ TDN or better).

Feeding of cottonseed products should be closely monitored in a bull's diet as naturally occurring gossypol found in these types of products can lead to temporary reduction in sperm quality when fed at high levels. Whole cottonseed should be limited to 10 percent of the diet in young bulls and 15 to 20 percent in mature bulls. Some data would indicate elimination of whole cottonseed from a young bull's diet. In addition, oil extraction method affects the level of gossypol in cottonseed meal.

Solvent-extracted cottonseed meal should be limited to 5 percent or less of the diet, while mechanical extracted cottonseed meal can be fed at levels of up to 15 percent of the total diet.

\section{Bull Breeding Soundness Evaluation}

A breeding soundness evaluation (BSE) is a quick and relativity inexpensive way of assessing a bulls breeding potential. BSE classifies a bull as satisfactory potential breeder, unsatisfactory potential breeder or classification deferred. These classifications are discussed in detail at the following website: HYPERLINK

"http://www.ivis.org/advances/Repro_Chenoweth/ spitzer/IVIS.pdf" and therefore, will not be discussed in this paper. A BSE should be conducted on a yearly basis by a qualified veterinarian. Bulls should be examined at least 60 days prior to the beginning of the breeding season. This allows for re-testing and replacement of bulls failing the examination. A BSE consists of four basic steps;

1. Visual assessment of the feet, legs, eyes, teeth and external genitalia;

2. Palpation of the accessory sex glands (prostrate and seminal vesicles);

3. Measurement of the scrotum as well as palpation of the testis and epididymis;

4. Collection and microscopic evaluation of a semen sample.

\section{Physical Examination}

Bulls must be able to cover large areas of land, often in rugged terrain which requires sound feet and legs. Feet and legs need to be examined to determine how mobile bulls will be in a breeding pasture. Bulls that have overgrown feet, corns and/or improper leg structure (post-legged) will not have the ability to mate with large numbers of cows during the breeding season and should be culled. Eyes should be examined as bulls locate estrous females primarily through visual observation rather than olfactory cues. Estrus females tend to be concentrated in one group which has been termed the sexual active group (SAG). The SAG consists of females that are in or close to estrus. Bulls locate estrus females through locating the SAG. Examination of the internal and external genitalia are important in assessing a bull's reproductive ability as injury or infection can render a bull infertile. 


\section{Yearling Scrotal Circumference}

Yearling scrotal circumference (YSC) provides a good indication of a bull's ability to produce sperm and is related to his own age at puberty as well as that of his daughters. The measurement should be taken at the largest diameter of the scrotum. Both testicles should be positioned next to each other and a flexible measuring tape should be placed snugly around the scrotum. Proper placement of the scrotal circumference tape is illustrated in Figure 1.

Testicles need to be descended into the scrotum, and should be of the same size and shape. Any irregular shape or swelling may indicate abnormal structure, illness or injury.

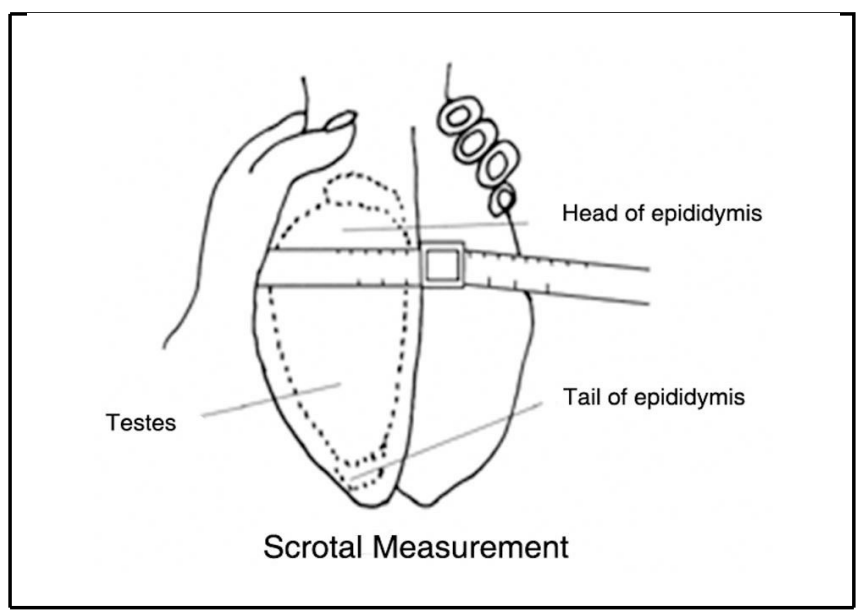

Figure 1. Circumference measurements are taken at the widest point on the scrotum. Testes and epididymis should be palpated as part of the BSE.

Using the actual scrotal circumference in centimeters, bull's age in days and Beef Improvement Federation (BIF) (table 3) or the appropriate breed association adjustment factor in the following formula will calculate a 365-day yearling scrotal circumference.

Adjusted 365-dayYSC $=$ YSC $+[(365$-Age $) X$ Age Adjustment Factor]

Using the adjusted 365-day yearling scrotal circumference allows for the comparison of scrotal circumference between different age bulls of the same or different breeds. Using the information below will allow for comparison of two bulls. For simplicity sake, the example will utilize information on Angus bulls.
Actual Scrotal Circumference Age

$\begin{array}{lll}\text { Bull A } & 39 \mathrm{~cm} & 410 \text { days } \\ \text { Bull B } & 34 \mathrm{~cm} & 320 \text { days }\end{array}$

Bull A Adjusted 365 YSC $=36+[(365-$ 410)] $X 0.0374=34.3 \mathrm{~cm}$

Bull B Adjusted 365 YSC $=34+[(365-$ 320)] $X 0.0374=35.7 \mathrm{~cm}$

Although bull A had the larger actual scrotal circumference, the main variation between the two bulls was actually difference in age.

Scrotal circumference is one of the most important measurements taken during a BSE. In the event that an actual birth date is not available on a bull then use of the following tables will provide threshold values for bulls to pass a BSE. Threshold values for bulls of Bos taurus breeding (Table 4) differ when compared to bulls of Bos indicus breeding (Table 5) due to delayed puberty in the Bos-indicus-influenced breeds. However, selecting for scrotal circumference is possible as sufficient variation exists in all breeds of cattle. In fact, through selection, Bos-indicus-influenced bulls have been able to achieve the same level of performance as their Bos taurus counterparts. Whenever possible, scrotal circumference should be adjusted to 365 days. This is especially applicable to seedstock producers who are selecting breeding animals.

Care should be taken to avoid selecting bulls with extra large scrotal circumference $(>44 \mathrm{~cm}$ adjusted to 365 days) that are pendulous because injury to the testicles can occur through movement around the pasture, rendering the bull infertile.

\section{Semen Characteristics}

Semen evaluation consists of microscopic examination of the sperm cells for concentration, motility (percent live) and morphology (percent normal). Electroejaculation is the most common method of semen collection, although some practitioners prefer massage of the internal reproductive genitalia. During semen collection, the veterinarian should expose the penis for visual 
assessment to determine if any abnormalities are present.

Studies have shown an increase in pregnancy rates for bulls that have satisfactory semen. Table 6 summarizes the results of a large study involving bulls that were examined for reproductive fitness prior to use versus unexamined bulls. In both trials, bulls that were screened prior to breeding increased pregnancy rate by 5 to 6 percent.

\section{Libido and Serving Capacity}

Libido is defined as sexual desire, while serving capacity is the ability to complete the act of mating. Although a bull has been classified as a satisfactory potential breeder, he can still be infertile if he lacks the desire or ability to mate. Tests have been developed to assess libido and serving capacity in beef bulls. Tests developed for

Bos-indicus-influenced breeds are different from tests for Bos-taurus-influenced breeds. Bos indicus breeds prefer the "pen" test, where estrus females are penned with bulls at a male-to-female ratio of 1:1.5 or 1:2. Bulls are observed for 30 minutes with mounts and completed services calculated. Bulls that achieve 2 or more services are considered high-serving-capacity bulls. Bulls completing one or no services during the 30-minute period are considered low-serving-capacity bulls.

For testing serving capacity in Bostaurus-influenced breeds, estrus or non-estrus heifers are placed in breeding crates. Male-to-female ratio is $1: 1$. Bulls achieving more than three services in the 30-minute period are considered high serving capacity, while those achieving 2 to 3 are moderate. Bulls achieving one or no services are classified as low serving capacity. Young bulls may need more than one test to accurately evaluate their serving capacity. Usually two tests given ten days apart will suffice (Sprott et al., 1997).

Studies have shown that high-serving-capacity bulls increased pregnancy rates as well as earlier conception dates in comparison to low-serving-capacity bulls. This resulted in $\$ 53$ more gross income in cows bred to high-serving-capacity bulls in comparison to low-serving-capacity bulls (Hawkins et al., 1988a).

\section{Social Behavior}

Social status within a bull battery can be complex. Age, mature size, aggressive behavior and other social interactions determine a bull's rank. In multiple-sire herds, bull ranking within the bull battery will determine to a large extent the number of progeny sired by each individual bull. Table 7 summarizes the data on four bulls pasture-mated over a 5-year period with typical results. Each year most of the calves born in the pasture were sired by one bull. Bull hierarchy changed over the five-year period but most of the calves were sired by one bull each year. DNA typing of parentage has shown similar results in large multiple-sired pastures. In order to circumvent bull dominance in a pasture mating system, bulls should be grouped by similar age, weight or equivalent social ranking within the herd before being placed in pastures. A subfertile dominant bull can lead to reduced pregnancy rates. Genetic merit should also be considered as a dominant bull with poor performance could have a large impact on economic returns in the cow herd.

\section{Fertility Associated Antigen}

Bulls with equivalent semen evaluation often have dissimilar results in pregnancy percentage. These results confounded researchers as to what was causing the variation between bulls evaluated as equal in terms of fertility. New research has led to the discovery of a protein that is produced by the accessory sex glands which is released into the seminal fluid upon ejaculation. This protein, identified as a heparin-binding protein and later termed fertility associated antigen (FAA), binds to the sperm cell membrane following ejaculation. Once attached to the sperm membrane, FAA facilitates the binding of sperm cells to "heparin-like" compounds in the female reproductive tract. This binding action is necessary to initiate capacitation, a necessary process that sperm cells have to undergo in order to fertilize ova. Research has shown that the degree of FAA attachment varied greatly between bulls. Further investigation found that bulls with detectable sperm-associated FAA increased pregnancy rate $16-19 \%$ in cow/heifers $(n=12,000)$ when bred naturally or through artificial insemination 
(AI) when compared to herdmate bull's deficient of FAA (Lenz, et al. 2000).

Recent developments have led to the production of a chuteside test with the capability of testing for FAA (T. Jackson, personal communication). This allows for bulls to be tested when a normal BSE is performed. Previously all samples had to be sent to a laboratory to be processed to determine whether a bull was positive or negative for FAA. A single test will suffice as FAA status appears to be constant throughout a bull's life under normal conditions. Young bulls tested negative for FAA would be the only exception, as they may improve as they become sexually mature. Expected results of using various percentages of negative and positive FAA bulls in a normal herd are listed in Table 8. Pregnancy rates increased in cows inseminated with semen from bulls with detectable FAA on spermatozoal membranes compared to semen for bulls devoid of FAA on membranes.

\section{Male to Female Ratio}

One bull to twenty-five cows is considered the normal male-to-female ratio. This is probably under usage of highly fertile bulls. Even in instances where cattle are grazed on extremely large pastures with large distances between water, a 1:25 male-to-female ratio is adequate. Research studies have shown that bulls evaluated to be highly fertile can settle large number of cows in a short period of time. The following table (Table 9) demonstrates that young two-year old bulls were able to mate successfully with up to 60 cows/heifers in a short period of time.

Notice that the number of heifers detected in estrus in 21 days was high in all groups. Estrus was detected in over $90 \%$ of the heifers in all pastures. The male-to-female ratio varied from 1:25 up to 1:60.

Generally speaking there was not a lot of difference in percent of heifers pregnant within twenty-one days between the groups regardless of male-to-female ratio. Two bulls (one with a ratio 1:44 and the other 1:60) had low pregnancy rates. Both of these bulls were observed to have problems with intromission. As this data points out, it is critical when using single sires in pasture mating that services are resulting in pregnancies. General guidelines for male-to-female ratios for appropriate ages are listed in Table 10. This assumes that a bull has passed a BSE, has the desire and ability to mate, is FAA positive and has adequate BCS (5 or greater).

After all of the above procedures have been performed, a simple method to insure that a bull is fertile is the use of the pass over rule. This consists of observing the first 8 to 10 cows that a bull mates and recording the date of service. Starting sixteen days later observe these same cows for 8 to 10 days recording those that have returned to estrus. Calculate the number of cows that have passed over the expected estrus date. If more than $50 \%$ of the cows within the given period return to estrus, further investigation needs to be done to ascertain factors that could be compromising fertility.

\section{Summary}

The proceeding management principles when properly applied will result in the use of highly fertile bulls. In summary use only bulls that meet the following criteria.

- Choose bulls with the right genetics for your herd. Select bulls that are the correct biological type for your environment and have appropriate genetic merit in economical traits such as: growth, carcass, and maternal ability.

- Provide adequate nutrition to insure that all bulls are in sufficient BCS at the beginning of the breeding season.

- Cull all bulls with structural problems, inability to mate, or low semen quality and those that produce calves of undesirable quality.

- Sort bulls by equivalent social status into breeding pastures to minimize the effect of the dominant bull siring the majority of the calves in any given pasture.

- Observe bulls at the start of the breeding season to determine that each bull has the ability to mate. Use the pass over rule to insure that each bull has the ability to impregnate cows. Remove bulls that have excessive numbers of cows returning to estrus. 
- Use only bulls that pass an annual BSE 60 days prior to the start of the breeding season. Re-test bulls that previously failed the examination. Cull bulls that fail to pass a BSE.

- Test bulls at least once to determine their fertility associated antigen (FAA) profile.

- Insure that an appropriate herd health program is in place.

\section{Literature Cited}

Geske, J. M., R. R. Schalles and K. O. Zoellner. 1995. Yearling scrotal circumference prediction equation and age adjustment factors for various breeds of beef bulls. Ag. Exp. Sta., Kansas State Univ. Rep. of Progress. 727:99.

Hawkins, D. E., B. B. Carpenter, L. R. Sprott, J. R. Beverly, H. E. Hawkins, N. R. Parrish, and D. W. Forrest. 1988. Proportion of early conceiving heifers is increased by high serving capacity bulls. J. Anim. Sci. 66 (Suppl.):246.

Lenz. R. W., H. Zhang, J. N. Oyarzo, M. E. Bellin, and R. L. Ax. 2000. Bovine fertility-associated antigen (FAA) and a recombinant segment of FAA improve sperm function. SSR, Abstract 80.

Osterhoff. in Improving Reproduction in Farm Animals. J. N. Wiltbank, Class notes, Animal Science 510, 1990, Brigham Young University, pg 382.

Rupp, G. P., L. Ball, M. C. Shoop, and P. J. Chenoweth. 1977. Reproductive efficiency of bulls in natural service: Effects of male to female ratio and single vs. multiple sire breeding groups. JAVMA 171:639-732.

Sprott, L. R., B. B. Carpenter and T. A. Thrift. 1997. Bull management for cow/calf producers.

Texas Agric. Ext. Bull. B-6064.

Wiltbank, J. N. and N. R. Parrish. 1986. Pregnancy rate in cows and heifers bred to bulls selected for semen quality. Theriogenology 25:779-783. 
Table 1. Multiplicative Effect of Factors Affecting Fertility in a Beef Cattle Herd.

\begin{tabular}{cccccccccc} 
Exam & $\begin{array}{c}\text { Cow } \\
\text { Fert. }\end{array}$ & & & $\begin{array}{c}\text { Bull } \\
\text { Fert. }\end{array}$ & & CDE $^{\mathrm{a}}$ & & $\begin{array}{c}\text { Cows } \\
\text { Mated }\end{array}$ & $\begin{array}{c}\% \\
\text { Pregnant }\end{array}$ \\
\hline 1 & 95 & $\mathrm{X}$ & 95 & $\mathrm{X}$ & 95 & $\mathrm{X}$ & 95 & $=81$ \\
2 & 100 & $\mathrm{X}$ & 100 & $\mathrm{X}$ & 100 & $\mathrm{X}$ & 85 & $=85$ \\
3 & 100 & $\mathrm{X}$ & 100 & $\mathrm{X}$ & 100 & $\mathrm{X}$ & 40 & $=40$ \\
4 & 100 & $\mathrm{X}$ & 40 & $\mathrm{X}$ & 100 & $\mathrm{X}$ & 85 & $=34$ \\
\hline
\end{tabular}

${ }^{a}$ Cows Detected in Estrus

Table 2. Five Major Problems in Bulls of Low Fertility

1. Lack of libido

2. Small scrotal circumference as a measure of sperm output

3. Unsatisfactory semen quality

- Morphology

- Motility

- Lack of Fertility Associated Antigen (FAA)

4. Low body condition score

5. Inability to copulate

- Problems with intromission

- Physical limitations-Structural problems with genitalia

- Feet, legs, eyes, general poor structure

Table 3. BIF age adjustment factors for scrotal circumference.

\begin{tabular}{lc}
\hline Breed & Adjustment \\
\hline Angus & 0.0374 \\
Red Angus & 0.0324 \\
Brangus & 0.0708 \\
Charolais & 0.0505 \\
Gelbvieh & 0.0505 \\
Hereford & 0.0425 \\
Polled Hereford & 0.0305 \\
Limousin & 0.0590 \\
Salers & 0.0543 \\
Simmental & 0.0543 \\
\hline
\end{tabular}

Table 4. Recommended scrotal circumference for Bos taurus bulls of various ages.

\begin{tabular}{|c|c|c|c|}
\hline Age & Very Good & Good & Poor \\
\hline $12-14$ months & $>34 \mathrm{~cm}$ & $30-34 \mathrm{~cm}$ & $<30 \mathrm{~cm}$ \\
\hline $15-20$ months & $>36 \mathrm{~cm}$ & $31-36 \mathrm{~cm}$ & $<31 \mathrm{~cm}$ \\
\hline $21-30$ months & $>38 \mathrm{~cm}$ & $32-38 \mathrm{~cm}$ & $<32 \mathrm{~cm}$ \\
\hline Over 30 months & $>39 \mathrm{~cm}$ & $33-39 \mathrm{~cm}$ & $<33 \mathrm{~cm}$ \\
\hline
\end{tabular}


Table 4. Recommended scrotal circumference for Bos taurus bulls of various ages.

Adapted from the Society of Theriogenology

Table 5. Recommended scrotal circumference for Bos indicus influenced bulls of various ages.

\begin{tabular}{|c|c|c|c|}
\hline Age & Very Good & Good & Poor \\
\hline 12 months & $>22 \mathrm{~cm}$ & $18-22 \mathrm{~cm}$ & $<18 \mathrm{~cm}$ \\
\hline 13 months & $>24 \mathrm{~cm}$ & $20-24 \mathrm{~cm}$ & $<20 \mathrm{~cm}$ \\
\hline 14 months & $>26 \mathrm{~cm}$ & $24-26 \mathrm{~cm}$ & $<24 \mathrm{~cm}$ \\
\hline 15 months & $>30 \mathrm{~cm}$ & $26-30 \mathrm{~cm}$ & $<26 \mathrm{~cm}$ \\
\hline $16-20$ months & $>31 \mathrm{~cm}$ & $28-31 \mathrm{~cm}$ & $<28 \mathrm{~cm}$ \\
\hline 21-24 months & $>32 \mathrm{~cm}$ & $29-32 \mathrm{~cm}$ & $<29 \mathrm{~cm}$ \\
\hline 25-31 months & $>35 \mathrm{~cm}$ & $31-35 \mathrm{~cm}$ & $<31 \mathrm{~cm}$ \\
\hline Over 31 months & $>39 \mathrm{~cm}$ & $34-39 \mathrm{~cm}$ & $<34 \mathrm{~cm}$ \\
\hline
\end{tabular}

Table 6. Bulls selected for semen quality at King Ranch.

\begin{tabular}{|c|c|c|c|c|c|}
\hline & \multicolumn{2}{|c|}{ Multiple Sire -1980} & \multirow[b]{2}{*}{ Control } & \multicolumn{2}{|c|}{ Multiple Sire - 1981} \\
\hline & Control & $80 \%+{ }^{a}$ & & $80 \%+^{a}$ & $70 \%+{ }^{b}$ \\
\hline Number of Exposed & 571 & 656 & 1179 & 522 & 769 \\
\hline Pregnant (\%) & 87 & 93 & 85 & 90 & 91 \\
\hline Difference $(\%)$ & & $6^{*}$ & & $5^{\star \star}$ & $6^{*}$ \\
\hline \multicolumn{6}{|c|}{${ }^{\mathrm{a}}$ Equal to or greater than 80 percent norml sperm cells. } \\
\hline \multicolumn{6}{|c|}{${ }^{\mathrm{b}}$ Equal to or greater than 70 percent normal sperm cells. } \\
\hline \multicolumn{6}{|l|}{${ }^{*} P<0.01$} \\
\hline${ }^{* *} P<0.005$ & & & & & \\
\hline
\end{tabular}

Wiltbank and Parrish, 1986

Table 7. Calves from different bulls used in pasture mating over five years.

\begin{tabular}{|l|c|c|c|c|}
\hline & & \multicolumn{2}{|c|}{ Bull } & \\
\hline & Oubass & Matie & Moreno & Slinger \\
\hline Age in Year 1 & 10 & 4 & 3 & 2 \\
\hline & \multicolumn{3}{|c|}{ Percentage of calves sired by each bull } \\
\hline Year 1 & 70 & 17 & 7 & 6 \\
\hline Year 2 & 76 & 18 & 6 & $0^{*}$ \\
\hline Year 3 & 12 & 63 & 12 & 12 \\
\hline Year 4 & $0^{*}$ & 72 & 12 & 15 \\
\hline Year 5 & $0^{*}$ & 25 & 62 & 12 \\
\hline *Absent this year & \multicolumn{5}{|c|}{ Adapted from Osterhoff, 1990 } \\
\hline
\end{tabular}


Table 8. Fertility within a herd of cows when different proportions of FAA-negative bulls are included with FAA-positive bulls.

\begin{tabular}{|c|c|c||}
\hline \hline Percent FAA-positive & Percent FAA-negative & Expected percent fertility \\
\hline 0 & 100 & 68.0 \\
\hline 50 & 50 & 76.5 \\
\hline 60 & 40 & 78.2 \\
\hline $75^{*}$ & $25^{\star}$ & 80.7 \\
\hline 80 & 20 & 81.6 \\
\hline 90 & 10 & 83.3 \\
\hline 100 & 0 & 85.0 \\
\hline *Expected ratio of bulls in a normal population & Reprotec, 2004 \\
\hline \hline
\end{tabular}

Table 9. Table 9. Bull to breeding female ratios in multiple and single-sire mating.

\begin{tabular}{|c|c|c|c|c|c|c|c|c|c|}
\hline \multirow[b]{2}{*}{ Factor } & \multicolumn{2}{|c|}{ Trial 1} & \multicolumn{3}{|c|}{ Trial 2} & \multicolumn{4}{|c|}{ Trial 3} \\
\hline & 1 & 2 & 1 & 2 & 3 & 1 & 2 & 3 & 4 \\
\hline Pasture Size (Ac.) & 1120 & 1120 & 296 & 323 & 320 & 320 & 960 & 323 & 943 \\
\hline $\begin{array}{l}\text { Male: female } \\
\text { ratio }\end{array}$ & $4: 99$ & $4: 99$ & $1: 44$ & $1: 44$ & $1: 43$ & $1: 60$ & $1: 60$ & $1: 60$ & $1: 60$ \\
\hline Bull age (yr) & $\mathrm{N} / \mathrm{A}$ & $\mathrm{N} / \mathrm{A}$ & 2 & 2 & 2 & 2 & 2 & 2 & 2 \\
\hline $\begin{array}{l}\text { Heifers detected } \\
\text { in estrus within } \\
21 \text { days }(\%)\end{array}$ & 97 & 95 & 95 & 96 & 98 & 92 & 98 & 95 & 98 \\
\hline $\begin{array}{l}\text { Heifers pregnant } \\
\text { within } 21 \text { days (\%) }\end{array}$ & 73 & 70 & 64 & 73 & $19^{*}$ & $40^{*}$ & 72 & 63 & 68 \\
\hline
\end{tabular}

Table 10. Recommended male-to-female ratio in bull of various ages.

\begin{tabular}{|c|c|}
\hline Age of bull & Male-to-female ratio \\
\hline $12-18$ months & $1: 15-25$ \\
\hline Two years & $1: 30-35$ \\
\hline Three to seven years & $1: 35-60$ \\
\hline Aged (seven plus) & $1: 30-40$ \\
\hline
\end{tabular}

